\title{
Evaluation of wear reduction measures for wheelsets and rails operated in high mountain conditions
}

\author{
Sergei Voznenko ${ }^{1}$, Anatoliy Falendysh ${ }^{1, *}$, Andrey Sumtsov ${ }^{1}$, Olha Kletska $^{1}$, and Miroslav \\ Blatnicky ${ }^{2}$ \\ ${ }^{1}$ Ukrainian State University of Railway Transport, 61050, Feuerbach square 7, Kharkiv, Ukraine \\ ${ }^{2}$ University of Zilina, Univerzitná 8215/1 01026 Žilina, Slovakia
}

\begin{abstract}
There are about 20 major factors influencing wear of railway system of a wheel, but the most critical include service and lubricant of rails. On the basis of locomotive depot Rodakovo the analysis of regularity of wear of a surface of wheels of the locomotive during the long period of time has been made and the method of correction of wheels has been offered and calculations which have shown that during operation of wheel couples there can be several corrections of a profile of a wheel before full grinding that leads to increase in life cycle of a wheel have been carried out. Also the approximate method for assessment of efficiency of introduction of methods of maintenance and repair of a wheel which includes the cost of life cycle of a wheel of the locomotive which will be developed further has been offered, estimating at the same time several methods, comparing their efficiency and choosing the most preferable options in the set parameters.
\end{abstract}

\section{Introduction}

Today, the rated service life of rails at the Ukrainian railways is 700 million tons gross, while at the American and European railways it is 2-3 times higher. The main factors that determine the service life of rails include the quality of rail steel, the quality of the rail production, the design of rails, the rail maintenance system, and the operation conditions of rails $[1,2]$.

According to $[3,4]$, there are about 20 main factors affecting the wear of the wheel-rail system:

- $\quad$ variation between wheel diameters;

- wheel profile;

- $\quad$ skewness of the axles of wheelsets;

- $\quad$ Track gauge;

- rail canting;

- $\quad$ rail profile;

- $\quad$ amplitude of irregularities;

* Corresponding author: fap_hiit@ukr.net 
- $\quad$ slope and curved track sections;

- $\quad$ tread of wheels on rails;

- lubrication of rails and a type of grease;

- climate;

- $\quad$ construction and type of the rolling stock bogie;

- weight of the train.

- $\quad$ speed and length of the train;

- direction of the train;

- type of locomotives and cars;

- $\quad$ shape of the wheel flange;

- $\quad$ type of the brake system;

- $\quad$ train control by the driver;

- $\quad$ periodicity and repair time of tracks and wheelsets

Article [5] presents operational observations and experimental studies, the results of mathematical simulation without regard to lubrication are summarized in Table 1. All the above factors affect the wear of rails and wheels, but the most critical ones include maintenance and lubrication of rails.

To prolong the service life of rails and reduce the damage with contact wear defects, polish the skid wears, pits, roughness and microdamaged surface layer of the metal should be ground away, both in the middle part of the top of the rail and in its lateral curls, forming a more convex outline of the upper surface of the top of rail, which shifts the wheel-to-rail contact area to the axle of the top, increases the strength of rails from $15-45$ to $80-95 \%$. Restoring of performance of rails in the track by forming a given convex shape of the lateral profile of the top is possible by using a grinding train with rotating grinding wheels located at different angles to the tread surface of the rails. Such grinding trains used abroad, at speeds up to $8 \mathrm{~km} / \mathrm{h}$, enable forming a convex profile of the top, removing the damaged metal layer up to $0.38 \mathrm{~mm}$ for one run $[1,2]$.

Table 1. Effect of different factors on the wear of the wheel-rail system

\begin{tabular}{|l|c|c|c|}
\hline \multicolumn{1}{|c|}{ Factor } & $\begin{array}{c}\text { Range of } \\
\text { measurements }\end{array}$ & $\begin{array}{c}\text { Degree of } \\
\text { effect, } \\
\%\end{array}$ & Grade \\
\hline $\begin{array}{l}\text { variation between } \\
\text { wheel diameters }\end{array}$ & $0-4 \mathrm{~mm}$ & $+(116-128)$ & $1^{\text {st }}$ \\
\hline $\begin{array}{l}\text { wheel profile } \\
\begin{array}{l}\text { Nkewness of the } \\
\text { wear }\end{array}\end{array}$ & $\begin{array}{c}\text { New } \\
\text { axles of wheelsets }\end{array}$ & $+4798)$ & $2^{\text {nd }}$ \\
\hline track gauge & $15101530 \mathrm{~mm}$ & $-(2128)$ & $3^{\text {rd }}$ \\
\hline Rail canting & $1 / 201 / 12$ & $+(27)$ & $4^{\text {th }}, 5^{\text {th }}$ \\
\hline Rail profile & $\begin{array}{c}\text { New of average } \\
\text { wear }\end{array}$ & $(8-160)$ & $6^{\text {th }}$ \\
\hline $\begin{array}{l}\text { Amplitude of } \\
\text { irregularities }\end{array}$ & $1-1.2$ & $+(3-4)$ & $7^{\text {th }}$ \\
\hline
\end{tabular}

According to [8], the wheel should be inserted into the contact surface of the rail to transfer the torque and ensure the adhesion of the wheel to the rail. In order to ensure the normal wear in the wheel-rail system with a slippage of up to $10 \%$, the stiffness ratio should be at least 1.2: 1, that is, with hardness of the wheel is $20 \%$ higher than that of the rails. However, since the late 1950s when bulk hardened rails began to be used, the ratio in the wheel-rail pair was set at 1:1.4, which today leads to poorer adhesion, increases slippage, and causes intensive wear of wheelsets. 
In $[6,7,10,11]$, based on the analysis of the global experience and experimental works, the conclusion has been made that an increase in the hardness of the wheels by $1 \mathrm{HB}$ within the operating range of hardness increases their wear resistance by $1-2 \%$. In addition, an increase in the hardness of the wheels from 250 to $600 \mathrm{HB}$ practically does not affect the wear and contact design life of the rails, and the contact fatigue design life of the wheels increases in proportion to the square of the increase in their hardness. Thus, an increase in the hardness of rails and the tread surface of wheelsets leads to an increase in their service life.

In [9], it was shown that the surface layer in the wheel-rail tribosystem in the actual operating conditions, especially the flanges and lateral surfaces of the rail, is strengthened. Moreover, the depth of the frictional layer reaches $0.01-0.03 \mathrm{~mm}$, and the increase in hardness at the surface is 220 to $1200 \mathrm{HV}$. According to the authors of [9], the strengthening mechanism of the friction layer is more complicated than simply cold work hardening or phase conversion hardening, although high contact loads up to 1000-1500 $\mathrm{MPa}$ and high temperatures up to $1000^{\circ} \mathrm{C}$ exist in small volumes of the actual wheel-rail contact. However, they exist for thousandths of a second. Therefore, it would be more correct to refer not to heating or cold work hardening of the surface layer, but to its high energy saturation. With such energy density, the metal in the shear layer flows amorphously, like liquid glass. After leaving the friction area, the metal in the slip band cools instantly, while retaining the amorphous structure of metal glass with a hardness of $800 \mathrm{HV}$ or more.

Currently, there are several techniques to increase the hardness of wheelsets, which are classified by the heating and cooling method:

- bulk hardening in furnaces;

- HFC hardening;

- laser, electron beam hardening;

- plasma arc (jet= hardening;

- electrocontact hardening;

- oxygen-acetylene hardening;

- laser cladding;

- plasma coating.

On the basis of Rodakovo locomotive depot of Ukrzaliznytsia, the analysis of regularities of wear of the tread surfaces of locomotive wheels has been carried out. The wear parameters were monitored on 10 diesel locomotives 2TE116 (120 wheelsets) for 30 months. During the period of the study, the locomotive mileage averaged 220-300 thousand $\mathrm{km}$. Also, 360 tyre grindings have been performed. The statistical analysis of operative wear parameters of tyres showed that by the time of grinding, neither clearance nor flange thickness parameters reach their maximum permissible values. As a rule, with a 2-3-fold reserve of the tyre body for clearance and flange thickness, the tyres are completely ground due to the value beyond the permissible limits of the slope parameter. The average clearance value before grinding was $2.0-2.5 \mathrm{~mm}$, and the average flange thickness was $27.8 \mathrm{~mm}$. And this is with allowable values of rolled products - up to $7 \mathrm{~mm}$, flange thickness - up to $25 \mathrm{~mm}$. In $77 \%$ cases, tyres were ground due to reaching the limiting value of the flange slope $(6.5 \mathrm{~mm})$ [12].

Figure 1 shows a typical example of a diagram of grinding tires with GOST 11018-87 profile and the following values of the geometric parameters of wear: flange thickness $27.4 \mathrm{~mm}$; clearance $0.9 \mathrm{~mm}$; flange slope $6.4 \mathrm{~mm}$.

A wheelset with such geometric parameters of wear should be rejected, and the tyres are ground to the initial profiles. In this example, a layer of metal weighing more than $35 \mathrm{~kg}$ is removed by grinding, and the tyre becomes $11 \mathrm{~mm}$ thinner. In this case, the ground profile 
acquires the geometric parameters of the new profile, namely: flange thickness $31.9 \mathrm{~mm}$; clearance $0.0 \mathrm{~mm}$; flange slope $10.3 \mathrm{~mm}$.

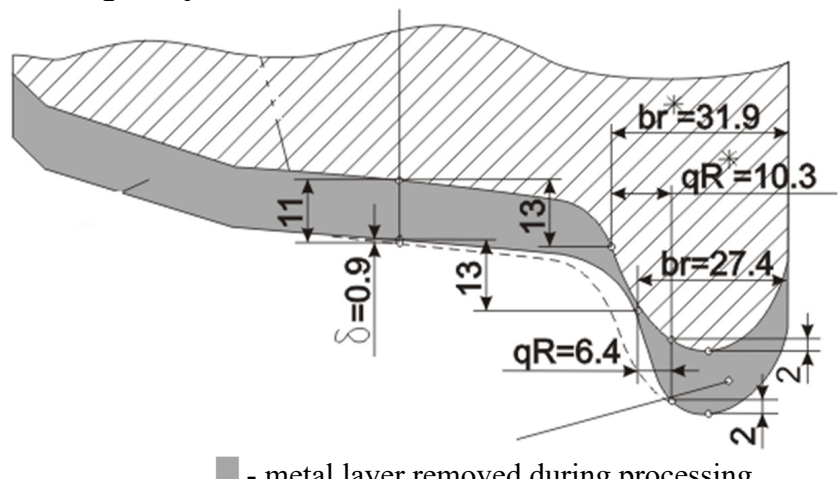

- metal layer removed during processing

Fig. 1. Diagram of profile restoration of tyre GOST 11018-87 using the existing technique

Since in this example the tyre before grinding had a significant clearance and flange thickness margin, it is expedient to perform not complete grinding, but only partial grinding, which would correct only by the wear indicator, the value of which are beyond the permissible limits, namely, the flange slope. The operation of the partial grinding of the tyre is called the correction of the flange profile. Figure 2 shows the profile correction diagram.

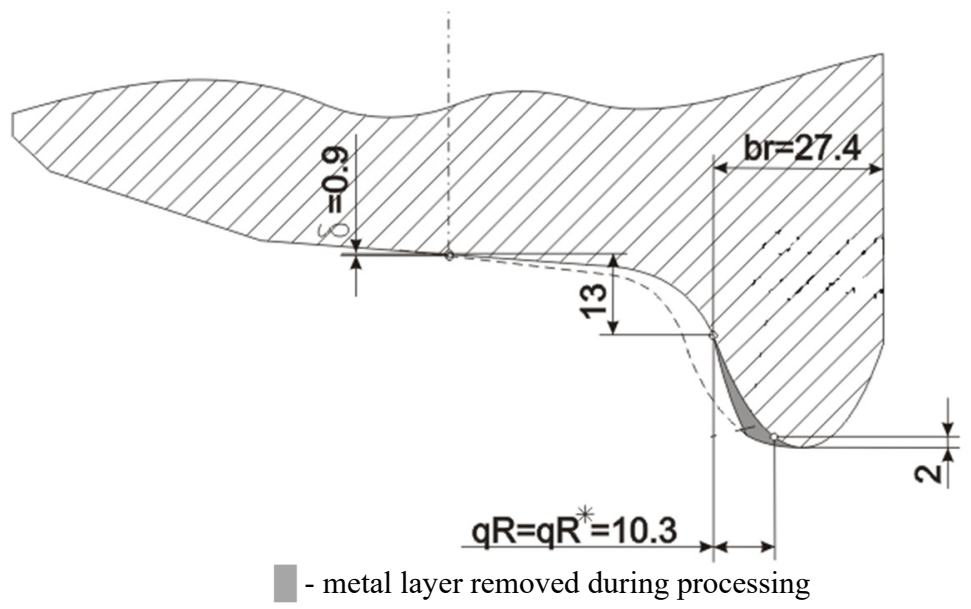

Fig. 2. Diagram of correction of the tyre flange profile

After correction, this profile retains the clearance of $0.9 \mathrm{~mm}$ and the flange thickness $(27.4 \mathrm{~mm})$ the same as before grinding, which is allowed by the "Instruction on formation, repair and maintenance of wheelsets of traction rolling stock of the Ukrainian railways of $1520 \mathrm{~mm}$ gauge" (VND 32.0 .07.001.2001) for further operation of the wheelset. In this case, the flange slope increases to the normative value of the slope of the initial profile $10.3 \mathrm{~mm}$.

When the tyre grinding technique described in this example is used and replaced with the flange profile correction, the metal layer removed when the profile of the wheels of one wheelset is restored, decreases from $70 \mathrm{~kg}$ (with the conventional methodology) to $1.8 \mathrm{~kg}$ (with the new methodology), and the tyre thickness remains unchanged. 
The conducted calculations show that during the operation of wheelsets, one to three flange profile corrections can be performed between complete grinding of tyres.

The above methodology of restoring the profile of the bandages, which involves replacing of complete grinding of the tyre with a flange profile correction allows us to hope for extension of the service life of tyres probably in 2.0-2.5 times.

The brief analysis suggests that increasing the wear resistance of the wheel-rail friction pair is a complex multifactor process that requires an integrated approach. An important direction of further studies is the rationale for searching for optimal combinations of various techniques by using an integrated approach to estimation of the wheel-rail problem.

To implement this approach, a simple principle of qualimetry, based on a direct comparison of indicators is applicable. Besides, comparable indicators should be used as indicators of evaluation. The most expedient method of estimation to be used is the weighting factors method, which is generally determined by the following formula

$$
K=\frac{\sum_{i=1}^{i=5} k_{n} \varphi(i)}{\sum_{i=1}^{i=5} \varphi(i)}
$$

where $K$ - indicator; $k$ - weighting factor; $\varphi_{p}$ - value of the parameter after the implementation; $\varphi$ - value of the parameter before the implementation.

The following parameters were chosen as the basic comparison parameters using the expert method:

- service life of the rail;

- service life of the tyre;

- life cycle cost of the rail and the wheelset.

The above indicators fully reflect the effectiveness of the use of individual methodologies to increasing the service life of the wheel-rail pair. Moreover, the integrated methodology takes into account the influence both on the tyre and on the top of rails.

Ranking of weighting factors using the expert method produced following results: $k_{1}=0.3 ; k_{2}=0.3$ and $k_{3}=0.4$. The first two indicators are equivalent and reflect the service life of the rail and the wheelset, and the last, more significant, the costs for its provision. Thus, both technical and economic components are taken into account. It should also be noted that the service life is a rational indicator, while the cost is the irrational one. In view of this, the formula for calculating the complex indicator takes on the following form.

$$
K=0.3 \varphi_{p 1} / \varphi_{1}+0.3 \varphi_{p_{2}} / \varphi_{2}+0.4 \varphi_{3} / \varphi_{p 3}
$$

The implementation of the proposed methodology for evaluating the measures to extend the lifespan of the wheel-rail pair has been conducted using the evaluation of two measures: plasma hardening of the bandage surface and the use of corrective grinding.

The complex estimation of parameter $K$ for the effect of the use of plasma hardening of wheelsets according to the data on operation of locomotives in mountain conditions is as follows. When bulk hardened rails are used, the application of reinforced tyres does not affect their service life, since the hardness of both surfaces is comparable. In this case, the service life of the wheelset before is 106.3 thousand $\mathrm{km}$ before hardening, and 137.2 thousand $\mathrm{km}$ afterwards. The life cycle cost was $42 \mathrm{UAH}, 860.4$ before the implementation and UAH 49,725.1 afterwards. As a result of the calculation, we obtain

$$
K=0.3+0.3 \cdot 137.2 / 106.3+0.4 \cdot 42860.4 / 49725.1=1.03 .
$$

The methodology for determining the effect of use of corrective grinding involves determination of the service life of the bandage and the life cycle cost. The wear of the rails does not change, and may be neglects in the evaluation. Thus, the first element of the 
indicator will be 0.3 . The service life of the wheelset is 106.3 thousand $\mathrm{km}$ before the implementation, and 149.1 thousand $\mathrm{km}$ afterwards.

According to the data provided by the locomotive depot, the life cycle cost will be UAH $42,860.4$ before the implementation of the methodology and UAH 38,657.9 after the implementation. Thus, the complex indicator will be

$$
K=0.3+0.3 \cdot 149.1 / 106.3+0.4 \cdot 42860.4 / 38657.9=1.16
$$

\section{Conclusions}

Comparison of the results of the first and second method of increasing the service life of the wheel-rail pair demonstrates that the corrective grinding is more advantageous vs. plasma hardening.

The proposed method for estimation of the measures to increase the service life of the wheel-rail pair will be further developed by estimating the simultaneous implementation of several measures with subsequent evaluation and comparison of their effectiveness and choosing the most preferable options.

\section{References}

1. Lapidus B.M. Zheleznodorozhnyy transport, 6, 46 - 48 (2013)

2. Karnushchenko N.N. Velichko D.V, Bobovnikova P.A., Transport Rossiyskoy Federatsii, 3, 10-14 (2010)

3. Sazonov V N., Zagitov E.D., Zheleznyye dorogi mira, 4 (2008)

4. Senkin P. L., Put i putevoye khozyaystvo, 5, 13-14 (2007)

5. Gozbenko V. Ye., Tuvshintur B., Sovremennye tekhnologii. Sistemniy analiz. Modelirovanie, 3, 191 - 197 (2015)

6. Lokomotiv-inform, 11, 20-22 (2008)

7. Moroz B.A., Maryutin K.A., Balanovskiy A.Ye., Lokomotiv, 19, 19-22 (1998)

8. Balanovskiy A.Ye., Glazkov V.S., Moroz B.A. et al., Sb. tr. SGUPS "Novye tekhnologii na VSZHD“, 57-65 (1999)

9. Balanovskiy A.Ye., Khayasi S.M. Problema iznosa pary treniya koleso-rels (kratkiy analiz i predlozheniya) (Irkutsk: Plazmoprotek, 1997)

10. Potakhov D.A., Izvestiya Peterburgskogo universiteta putey soobshcheniya, 1, 139 147 (2013)

11. Buynosov A.P. Metody povysheniya resursa kolesnykh par tyagovogo podvizhnogo sostava: Monografiya (M.: GOU "Uchebno-metodicheskiy tsentr po obrazovaniyu na zheleznodorozhnom transporte", 2010) 